\title{
High performance human resource system and organizational citizenship Behaviors: An empirical study in Vietnam
}

\author{
Giang Thi Huong Vu $\mathbf{u}^{\mathrm{a}}$, Duong Tuan Nguyen ${ }^{\mathrm{b}}$ and Thai Phong Le $\mathrm{c}^{\mathrm{c}^{*}}$
}

${ }^{a} P h D$ Student, Department of Industrial Administration System, Graduate School of Economics, Nagoya University, Nagoya, Japan

${ }^{b}$ PhD Student, Business Administration Department, National Sun Yat-sen University, Kaohsiung, Taiwan

${ }^{c}$ Associate Professor, PhD, Faculty of Business Administration, Foreign Trade University, Hanoi, Vietnam

CH R O N I C L E

Article history:
Received: February 10, 2020
Received in revised format:
March 202020
Accepted: April 10, 2020
Available online:
April 12, 2020
Keywords:
Job satisfaction
High performance human re-
source
Mediation model
Organizational citizenship behav-
ior
Vietnam

\begin{abstract}
The present study examines the relationship between high performance human resource (HPHR) system and organizational citizenship behavior (OCB) in Vietnamese enterprises, and explores the mediating role of job satisfaction in this interaction. Data collected from 179 line managers working in Vietnamese companies by structured questionnaires. The results indicate that the positive relationship between HPHR system and organizational citizenship behavior was mediated by job satisfaction. The study also provides evidence in terms of the application of HPHR system to foster the organizational outcomes and contributes to understanding the underlying mechanism in human resource system and employee's behaviors relationship.
\end{abstract}

(C) 2020 by the authors; licensee Growing Science, Canada

\section{Introduction}

Human resource management (HRM) literature has highly registered the use of HRM practices to furnish employees' attitude and behavior to achieve business objectives. The resource-based theory indicated it is necessary that organizations adopt HRM practices which can be easily inimitable and encourage employees to create added value to organizations in order to compete in the market (Wright \& McMahan, 1992). There are several HRM systems which are beneficial for employees and organizations such as high performance human resource (HPHR) system (Huselid, 1995), high commitment human resource system and high involvement human resource system (Guthrie, 2001). In which, HPHR system is known as "a system of human resource practices designed to enhance employees' skills, commitment, and productivity in such a way that employees become a source of sustainable competitive advantage" (Datta, Guthrie, \& Wright, 2005, p. 136) has a positive relationship with numerous indicators of organizational performance (Combs, Liu, Hall, \& Ketchen, 2006). A growing body of work from various disciplines characterized HPHR system as a modern form of HRM system to enhance organizational performance. Besides, a number of scholars have attempted to explore the relationship of HPHR system with employees' attitudinal and behavioral outcome. Recently, HR scholars have increasingly paid attention to investigations into the linkage between HPHR system and employee's behaviors, which are related to the organizational effectiveness (Delery, 1998; Wright, McMahan, \& McWilliams, 1994). Specifically, the researchers have turned their attention to study the effect of HRM systems on individual

* Corresponding author. Tel: +84-24-38356800 (ext.528)

E-mail address: lethaiphong@ftu.edu.vn (T. P. Le)

(C) 2020 by the authors; licensee Growing Science, Canada doi: $10.5267 /$ j.msl.2020.4.015 
employee attitudes and behaviors (Allen, Shore, \& Griffeth, 2003; Kuvaas, 2008; Wright, Gardner, \& Moynihan, 2003; Zacharatos, Barling, \& Iverson, 2005), job satisfaction and affective commitment (Allen et al., 2003; Takeuchi, Chen, \& Lepak, 2009; Wu \& Chaturvedi, 2009), trust in management and organizational commitment (Whitener, 2001). Sun, Aryee, and Law (2007) indicated that organizational citizenship behavior (OCB) constituted the mechanism through which HPHR system positively impacts organizational performance. Though there exists a debate on mediating process and mechanisms involved in HRM effects, which is called "black box" problem (Paauwe, 2009; Ramsay, Scholarios, \& Harley, 2000). In addition, organizational commitment and job satisfaction as mediators in the positive linkage between HRM systems and individual behaviors within an organization have also investigated; however, the findings have been varied (Allen et al., 2003; Kehoe \& Wright, 2013; Kuvaas, 2008; Snape \& Redman, 2010a). Therefore, it is necessary for future research to examine the impact mechanism of HRM practices on individual behaviors (Alfes, Shantz, Truss, \& Soane, 2013). However, few studies have been devoted on this issue. This study aims to explore the mediating mechanism through which HPHR system influence OCB. To achieve this objective, this research based on social exchange theory (Blau, 1964). From this theoretical perspective, the employees are assumed to reciprocate the companies' employment practices by their performance, commitment and retention (Pittino, Visintin, Lenger, \& Sternad, 2016). The key argument in this research is that when the company applies the HPHR system that provides employees more opportunities to take part in decision making process, motivates employees by delivering recognition, as well as improve employees' skills, knowledge, and ability to perform their job roles (Lepak, Liao, Chung, \& Harden, 2006). Consequently, the employees would feel more satisfied with their jobs and they are thus willing to reciprocate in a positive manner by working harder and becoming more committed to the organization, and thereby engaging more in OCBs (Appelbaum, 2000; Settoon, Bennett, \& Liden, 1996). The empirical study focuses on Vietnam context with the aim of demonstrating the generalizability and application of Western theories to the Asian context. Being one of Asia's fastestdeveloping countries, Vietnam has a high average annual growth, and Vietnam organizations strive to utilize HPHR system in reinforcing employee in-role performance. However, there are a few studies on the impact of HPHR system on Vietnamese organizational performance. In addition, the SHRM literature highlights that most studies examining the relationship between HPHR system and OCB have been conducted in the Western countries. Therefore, this study will be evidence to foster the importance of application HPHR system to foster the organizational outcomes and contributes to understanding the underlying mechanism in human resource system and employee's behavior relationship.

\section{Theoretical background and hypothesis development}

\subsection{High performance human resource systems}

A large number of researchers have focused on exploring the impact of individual HRM practices on employee behaviors at the individual level. However, some recently HRM scholars argued that HRM practices need to be treated as a set or bundle of individual HRM practices rather than single practices to assess their influence on employee outcomes (Gould-Williams \& Mohamed, 2010; Snape \& Redman, 2010). Some recent studies examined multiple HR practices as a system; specifically, HRM system was mentioned as an HPHR system (Huselid, 1995) or as an HRM practice configuration (Delery \& Doty, 1996; Lepak \& Snell, 1999). Wright and Boswell (2002) argued that single HRM practices can create an effect of substitution, complement, or even conflict with other HRM practices. A coherent "system" or "bundle" (Delery \& Doty, 1996; MacDuffie, 1995) of HRM practices which can bring to higher effectiveness, as in the synergistic relationship, any HRM practice can support and enhance the effectiveness of one another; thus, the effect of entire HRM system is greater than the sum of single effects from each HRM practice alone (Becker, Huselid, Pickus, \& Spratt, 1997; Ichniowski, Shaw, \& Prennushi, 1997). This leads to the perception of HRM systems rather than single HRM practices which may be appropriate for identifying employee behaviors and attitudes (Guest, Conway, \& Dewe, 2004; Guest, 2004; Paauwe, 2009). Hence, there is a need to study the impact of the entire system of HRM practices on employee behaviors. HPHR practices are considered as "coherent practices that enhance the skills of the workforce, participation in decision making, and motivation to put forth discretionary effort" (Appelbaum, 2000, p. 26) and "result in ... superior intermediate indicators of firm performance and sustainable competitive advantage" (Way, 2002, p. 765). Although HPHR system is a subject in many HRM research, there exits little consensus among HR scholars about the specific HRM practices to be comprised in the configuration of HPHR system (Becker \& Gerhart, 1996; Collins \& Smith, 2006; Datta, Guthrie, \& Wright, 2005; Delaney \& Huselid, 1996). The specific HRM practices comprised in HPHR systems have embedded numerous across research; however, a commonality of HRM practices in high performance approach focuses on developing workforce skills and ability, increasing employee motivation for discretionary effort, and providing employees with opportunity to fully utilize their knowledge, skills and other attributes in their jobs (Appelbaum, 2000; Combs, Liu, Hall, \& Ketchen, 2006; Guest, 1997) to perform behaviors consistent with organizational goals. Therefore, HPHR systems are determined by the combination of single HRM practices that collectively influence organizational performance. Particularly, based on dimensions of HPHR systems adopted by Sun et al. (2007), our study included HRM practices which develop ability such as selective staffing, extensive training; enhance motivation such as resultsoriented appraisal, incentive reward, employment security; and create opportunities such as internal mobility, encouragement of participation, clear job description (Sun et al., 2007).

\subsection{The linkage between high performance human resource system and organizational citizenship behavior}

The linkage between an organization and its employees can be conceptualized as "involving economic and social exchange" (Snape \& Redman, 2010, p. 1224). Economic exchange involves exclusively in a specific contract relationship, which only 
requires particular performance of contractual obligations, does not expect performance beyond the detailed contractual terms. In contrast, social exchange is based on imperfectly specific terms and norms of reciprocity (Blau, 1964). Social exchange theory shows that discretionary benefits offered to the exchange partner are paid back in a discretionary way in the longer term (Blau, 1964; Rhoades \& Eisenberger, 2002). Social exchange perspective gives a conceptual framework to explain how employee perceptions of HRM system are related to employee behaviors. If employees receive socio-emotional and economic benefits from their organizations, they will return discretionary role behaviors to their organizations. These discretionary role behaviors are considered as forms of organizational citizenship behaviors (OCB). OCB commonly known as an extra-role behavior is defined as "individual behavior that is discretionary, not directly or explicitly recognized by the formal reward system, and that in aggregate promotes the effective functioning of the organization"(Organ, 1988, p. 4). OCBs go beyond the basic requirements of the job and thereby, they are not easily enforced by the threat of sanctions (Smith, Organ, \& Near, 1983). HRM practices may be viewed as an input into the social exchange process (Snape \& Redman, 2010). HRM systems can develop an environment which can encourage or even discourage OCB (Morrison, 1996). When employees receive longterm investment from organizations through HPHR practices, they feel obligated to reciprocate with discretionary role behaviors that are typically conceptualized in terms of OCB (Gong, Chang, \& Cheung, 2010; Shaw, Dineen, Fang, \& Vellella, 2009; Sun et al., 2007). As Hannah and Iverson (2004, p. 339) asserted: "HRM practices are viewed by employees as a "personalized" commitment to them by the organization which is then reciprocated back to the organization by employees through positive attitudes and behavior". In a similar vein, Leana and Van Buren (1999) indicated that human resource management practices foster the development of high-quality exchange relationship leading employees to assume the role of good organizational agents. Indeed, they stressed that "if individuals believe that their efforts are an integral part of a collective, they are more likely to spend time doing things the organization and/or its members find useful (e.g., engaging in extra-role behavior or working cooperatively) and less time doing things benefiting the individual but not the organization (e.g., social loafing, self-promotion, or unwillingness to cooperate)" (Leana \& Van Buren, 1999, p. 548). Further, in employee - organization relationships, the mutual investment reflected in HPHR system will motivate employees to perform better on their core tasks and also demonstrate more citizen behaviors to their organizations (Tsui, Pearce, Porter, \& Tripoli, 1997). HPHR system, namely selective staffing, extensive training, internal mobility, employee security, clear job description, result-oriented appraisal, incentive reward and participation, provides employees with multiple social resources such as appreciation, recognition, prestige, fairness, growth and empowerment, which foster social exchange relationship with employees. Through the implementation of HPHR system, employees are likely to perceive investment from their organizations and reciprocate by expanding their job roles and engaging more in OCB (Morrison, 1996). In line with this argument, the findings of (Sun et al., 2007) from cross-level analysis reported that HPHR practices were positively related to service-oriented OCB. Moreover, based on a collective social exchange approach, a study conducted at the middle management group level in China firms found that HPHR system had a positive relationship with collective OCB through collective affective commitment (Gong et al., 2010). Hence, we propose that:

\section{Hypothesis 1: There is a positive relationship between HPHR system and OCB.}

\subsection{The relationship between high performance human resource system and job satisfaction}

As mentioned above, the conceptualization of HPHR system assumed that such systems contain a set of HRM practices that have an impact on employee's motivation and attitudes (Huselid, 1995). HPHR system can encourage employee participation in decision making, motivate employees as well as enhance knowledge, skill and ability of employees to perform better their job duties (Lepak et al., 2006). Employees will feel satisfied when their organization offers them opportunities to participate in decision making process, deliver training programs to improve their knowledge, skill and ability to fulfil their tasks and provide clear communication between hierarchies (Guest, 1999, 2004; Guzzo \& Noonan, 1994). Accordingly, HPHR system plays an important role in increasing employee job satisfaction (Harley, 2002; Macky \& Boxall, 2007). There is also increasing body of work providing evidence that job satisfaction is associated with HPRH systems (Appelbaum, 2000; Guest, 1999; Harley, 2002; Macky \& Boxall, 2007). Particularly, Guest (1999) indicated that employees who assessed experiencing higher numbers of HRM practices reported a higher level of job satisfaction. Similarly, Macky and Boxall (2007) also asserted that high performance work practices were generally related to improvement of employee attitudes, especially would have more satisfied employees (Appelbaum, 2000; Guest, 1999). Takeuchi, Chen, and Lepak (2009) conceptualized and tested HPHR practices as a system to explore the influence of an overall HRM system on individual employee attitudes, and also acknowledged the positive relationship between HPHR system and job satisfaction. Consequently, we claim that the use of HPHR system makes employees feel more satisfied because this system allows them to have more voice in organizational goal setting, empower them more job autonomy, and also provide them more training and development opportunities. Employees are more likely satisfied with their jobs simply because they respond to a HPHR system implemented within their organization. Therefore, we propose that:

Hypothesis 2: The implementation of HPHR system is positively related to job satisfaction.

\subsection{Job satisfaction and organizational citizenship behavior relationship}

Job satisfaction is known as one of crucial job attitudes (George \& Jones, 1997; Jehn, Northcraft, \& Neale, 1999; MacKenzie, Podsakoff, \& Ahearne, 1998). The OCB literature recognized the positive relationship between job attitudes and OCB. The initial research on main antecedents of OCB focused on employee characteristics, one of which is a general affective "moral" 
factor (Bateman \& Organ, 1983; O'Reilly \& Chatman, 1986; Smith et al., 1983). The affective "moral" factor viewed as underlying perceptions of fairness and leader supportiveness, job satisfaction and organizational commitment (Organ \& Ryan, 1995) had a significant relationship with OCB and was considered as important determinants of OCB (Podsakoff, MacKenzie, Paine, \& Bachrach, 2000). In the critical review of theoretical and empirical OCB literature, Podsakoff et al. (2000) identified job attitudes such as employee satisfaction and organizational commitment, perception of fairness as one of antecedents of OCB, which are more strongly associated with OCB than the others. The positive influence of job satisfaction and organizational commitment on citizenship behaviors have been examined in several previous research (Bateman \& Organ, 1983; Moorman, 1991; Moorman, Niehoff, \& Organ, 1993; Organ, 1988, 1990; Smith et al., 1983). Similarly, the positive link between job satisfaction and extra-role behaviors was also explored in the study of sale employees (MacKenzie et al., 1998). Employees satisfied with their job will respond in kind by showing willingness to engage more in extra-role behaviors. The conceptual basis for predicting job satisfaction - OCBs relationship draws upon social exchange theory (Blau, 1964), which indicates that in given certain conditions, employees will seek to reciprocate those who benefit them. As employees' satisfaction origins from organizational efforts such use of HPHR system to enhance employees' competencies, create development opportunities, and such efforts are inferred as non-manipulative and volitional intent, employees will seek to pay back those organizational efforts with more OCBs. A positive relationship between job satisfaction and OCBs thus is expected.

Hypothesis 3: There is a positive influence of job satisfaction on OCB.

\subsection{Job satisfaction as mediator in high performance human resource system - organizational citizenship behavior} relationship

Although the empirical research asserted the positive link between HPHR practices and OCB (Alfes, Shantz, Truss, \& Soane, 2013; Gong et al., 2010; Snape \& Redman, 2010; Sun et al., 2007), this link likely relies on some intervening attitudinal explanation that was not directly influenced by immediate rewards such as extensive training, performance-based incentives from the organization, such as HPHR system, to increase extra-role behavior (Kehoe \& Wright, 2013). Further, Guest (1997) proposed a theoretical model on HR practices - performance relationship and suggested that employee perceptions of HR practices result in attitudinal outcomes, which consecutively produce behavioral outcomes such as OCB. Particularly, the HPHR system-OCB relationship can be better explained indirectly through the influence of HPHR system on job satisfaction. According to HRM theorist, behavioral and attitudinal outcomes of employees are shaped by "the communicative nature of everyday HR practices" (Guzzo \& Noonan, 1994, p. 453). In addition, Rousseau and Greller (1994, p. 385) also noted that “a person's experience in an organization ... is shaped by personnel actions such as recruiting, appraising performance, training, and benefits administration". The communicative feature of HPHR can lead to the development of psychological relationship between employees and their organizations through building trust and producing norms of reciprocity (Arthur, 1994; Pfeffer, 1994). Previous studies mentioned to HPHR system as a mutual investment approach, which was developed based on a reciprocal relationship and social exchange perspectives (Tsui et al., 1997). From social exchange theory, HPHR system provides employees opportunities to take part in decision making process, motivates employees by delivering recognition, as well as improve employees' skills, knowledge, and ability to perform their job roles (Lepak et al., 2006), which make employees feel more satisfied. Employees are thus willing to reciprocate in a positive manner by working harder and becoming more committed to the organization, and thereby engaging more in OCBs (Appelbaum, 2000; Settoon et al., 1996). Through mutual reinforced HPHR system, the organization provides their employees substantial inducements, which extend beyond monetary rewards, results to more job satisfaction. Consequently, employees are willing to contribute in order to achieve organizational goals as well as are more motivated than others to exert considerable efforts in extra role performance to further organizational effectiveness, even if they do not expect to be directly compensated for this behavior. Thus, we propose that:

Hypothesis 4: Job satisfaction will mediate the relationship of HPHR system and OCB.

\section{Research methodology}

\subsection{Data and sample}

In this study, the data were collected from Vietnamese firms, which were located in big cities in Vietnam, namely Hanoi, Hochiminh and QuangNinh. These firms represented various industries, size, and ownership types. The structured questionnaires were sent to the target respondents who were line managers of Vietnamese firms. The study excluded responses from non-line managerial respondents; and finally, there were total 179 usable questionnaires for the analysis. The information of participants in this research was assured to be confidential and anonymous. Of the sample, most of the respondents were working in limited and joint stock companies; particularly, 18 are in private companies, 76 are in limited companies, 64 are in joint stock companies, 14 are in public companies and the rest are in other ownership types. The size of the company is very diverse with $23.5 \%$ having from 10 to 50 staffs and $17.9 \%$ of from 100 to 200 staffs. Especially, there are 52 companies having more than 300 employees, accounting for $29.1 \%$. Regarding the industry, approximately a half (49.2\%) of the respondents were working in commerce and service section and just one-thirds $(30.7 \%)$ in industry and construction, and approximately one-tenth (7.8\%) in agriculture, aquaculture and fishery section. The majority of respondents had more than 3 years of working experience (89.9\%). These figures are quite consistent with the range of age of respondents with more than $90 \%$ of them are more than 26 years old. Concerning the educational background, higher education is dominated with $92.9 \%$ of respondents having a bachelor or master degree. This indicated a favorable picture of well-educated respondents. They have 
enough working time to have a good insight of company. Besides, $62.6 \%$ of respondents is male and $37.4 \%$ is female. People who answered the questionnaire are working for different departments. This result indicated that the sample is reliable and able to represent the target population.

\subsection{Measurement}

The questionnaire was designed, translated into Vietnamese, and pretested. The draft questionnaires were developed in English, and then independently translated into Vietnamese by two Vietnamese bilingual academics who are in charge of conventional translation and back-translation. Then, the questionnaires were reviewed by two HR managers of Vietnamese companies to test the accuracy of the professional terms and perspicuity. The main content of the questionnaire comprises 60 questions focusing on surveying the respondents' assessment on HPHR, job satisfaction, and OCB. Concerning these quantitative questions, respondents are required to rate their agreement with each statement based on a 7-point Likert scale, varying from 1-strongly disagree to 7-Strongly agree. In the general information part, company size in term of the number of employees, industry, type of ownership, tenure, education background, working department, gender and range of age of respondents are also contained by choosing among proposed alternatives.

High performance human resource system: A 27 item HPHR scale adapted from L.-Y. Sun et al. (2007) was used to measure HPHR system. The HPHR subscales, including selective staffing, extensive training, internal mobility, employment security, clear job description, result-oriented appraisal, incentive reward, were measured. Respondents were required to choose an option with seven-point Likert-type scale ranging from 1 - "strongly disagree" to 7 - "strongly agree" for evaluating statement on HPHR practices. Some item examples are " There are formal training programs to teach new hires the skills they need to perform their job.", "Performance is more often measured with objective quantifiable results.", or " Promotion in this organization is based on seniority (reverse-coded)". The study conducted factor analysis, including both exploratory and confirmatory to test the validity of the measurement of HPHR practices. Firstly, the study used SPSS ver22 to run exploratory factor analysis (EFA). The EFA results removed 7 items because of their factor loading value less than cut off point of 0.5 and their cross-loadings on other factors; and the remaining 20 items hence were grouped into 6 factors namely job description and appraisal, extensive training, employee security, internal mobility, selective staffing and incentive reward (as shown in Table 1).

Table 1

Exploratory factor analysis results of HPHR System

\begin{tabular}{|c|c|c|c|c|c|c|}
\hline \multicolumn{7}{|c|}{ Component } \\
\hline HPWS & Job description \& appraisal & Extensive training & Internal mobility & Employee security & \multirow[t]{2}{*}{ Incentive reward } & \multirow[t]{2}{*}{ Selective staffing } \\
\hline APP3 & .550 & & & & & \\
\hline DES1 & .614 & & & & & \\
\hline DES2 & .718 & & & & & \\
\hline DES3 & .760 & & & & & \\
\hline APP1 & .830 & & & & & \\
\hline APP2 & .884 & & & & & \\
\hline TRA2 & & .789 & & & & \\
\hline TRA3 & & .814 & & & & \\
\hline TRA4 & & .852 & & & & \\
\hline TRA1 & & .890 & & & & \\
\hline $\mathrm{MBO} 3$ & & & .539 & & & \\
\hline MBO1 & & & .698 & & & \\
\hline $\mathrm{MBO} 2$ & & & .866 & & & \\
\hline PAR2 & & & & .505 & & \\
\hline SEC2 & & & & .659 & & \\
\hline SEC1 & & & & .813 & & \\
\hline REW1 & & & & & .651 & \\
\hline REW2 & & & & & .877 & \\
\hline STA2 & & & & & & .610 \\
\hline STA1 & & & & & & .686 \\
\hline Kaiser-Mey & er-Olkin Measure of Samplin & dequacy Barlett's Te & of Sphericity & 0.857 & & \\
\hline Approx. Ch & i-square & & & 2022.0 & $3 \mathrm{df}=190$ (Sig. $<0$ & \\
\hline $\begin{array}{l}\text { Cronbach's } \\
\text { Alpha }\end{array}$ & .891 & .905 & .700 & .687 & .751 & .814 \\
\hline
\end{tabular}

Moreover, the confirmatory factor analysis was also employed to ascertain factor structure of 20 HPHR items explored in EFA. The CFA findings indicated a HPWS 6 factor model with chi-square of 279.466 (p-value $<0.001)(\mathrm{CMIN} / \mathrm{df}=2.086$, $\mathrm{GFI}=0.872, \mathrm{AGFI}=0.804, \mathrm{CFI}=0.931, \mathrm{TLI}=0.91, \mathrm{RMSEA}=0.077)$. These results confirmed a six factor measurement model of HPHR practices with a good model fit (Byrne, 2009; Hu \& Bentler, 1998).

Organizational citizenship behavior: Following Organ (1988, 1990) and Podsakoff et al. (2000), a set of 22 items with a response scale ranged from 1 - "strong disagree" to 7 - "strongly agree" is used to measure employees' OCB (e.g. "Attends functions that are not required, but help the company image"). In the measurement scales, there were some reversed items used, such as "I consume a lot of time complaining about trivial matters". OCB is divided into some dimensions, namely civic virtue, sportsmanship, altruism, courtesy, and conscientiousness (Organ, 1988, 1990; Podsakoff et al., 2000). Similar to measurement of HPHR system, both exploratory and confirmatory were employed to test the validity of the measurement of OCB. 
In the EFA results, four items were removed due to their low factor loading; and the remaining 18 items hence were grouped into 3 factors; namely, sportsmanship, altruism and courtesy, conscientiousness and civic virtue (as shown in table 2). Moreover, results of confirmatory factor analysis also affirmed that the three factor model of OCB achieved a good model fit with chi-square of $218.372(\mathrm{p}$-value $<0.001)(\mathrm{CMIN} / \mathrm{df}=2.003, \mathrm{GFI}=0.88, \mathrm{AGFI}=0.83, \mathrm{CFI}=0.95, \mathrm{TLI}=0.94, \mathrm{RMSEA}=$ 0.074) (Byrne, 2009; Hu \& Bentler, 1998).

Table 2

Exploratory Factor Analysis results of OCB

\begin{tabular}{|c|c|c|c|}
\hline \multicolumn{4}{|l|}{ Component } \\
\hline $\mathrm{OCB}$ & Altruism and courtesy & Conscientiousness and civic virtue & Sportsmanship \\
\hline COUR 2 & .545 & & \\
\hline ALT4 & .631 & & \\
\hline COUR1 & .657 & & \\
\hline ALT5 & .694 & & \\
\hline ALT1 & .753 & & \\
\hline ALT3 & .855 & & \\
\hline ALT2 & .941 & & \\
\hline CONS5 & & .490 & \\
\hline CONS1 & & .494 & \\
\hline CONS3 & & .639 & \\
\hline CIV1 & & .645 & \\
\hline CONS2 & & .646 & \\
\hline CIV4 & & .900 & \\
\hline CIV3 & & .942 & \\
\hline SPO1 & & & .564 \\
\hline SPO3 & & & .708 \\
\hline $\mathrm{SPO} 2$ & & & .789 \\
\hline SPO4 & & & .809 \\
\hline Kaiser-Meyer-Olkin & oling Adequacy Barlett's & ericity & \\
\hline Approx. Chi-square & & & $\mathrm{df}=153$ Sig. $<0.001$ \\
\hline Cronbach's alpha & .908 & .898 & .816 \\
\hline
\end{tabular}

Job satisfaction: Job satisfaction was measured by 11 items with 7-point scale with endpoints "strongly disagree" and "strongly agree" developed and assessed by (Brayfield \& Rothe, 1951). For example, the respondents rate their agreement toward these statement "Most days I am enthusiastic about my work", or "I consider my job rather unpleasant" (reversed item). After eliminating the item JS8 - "Each day of work seems like it will never end" - with the corrected item-total correlation is also so low at 0.220 , the Cronbach's alpha for Job satisfaction is 0.902 . The results indicated that the measures in this study achieved the adequate reliability and validity. The results of reliability of scales were a consequence of a well-designed, clear questionnaire, well-grouped, and good samples. And the measures gain the extreme reliability (Hair, Black, Babin, Anderson, \& Tatham, 1998; Nunnally \& Bernstein, 1994).

Control variables: The study used size and ownership type of the firms that line managers worked for as the control variables, since these factors have been argued to have an effect on the implemented HPHR system (Boyne, Poole, \& Jenkins, 1999; Teo, 2002). Besides, the study also controlled industrial sectors such as manufacturing and service sectors, as this variable is likely to impact HPHR system (Bennett, Ketchen Jr, \& Shultz, 1998). Additionally, the tenure of respondents was controlled because this may have an influence on their perceptions of implemented HPHR system (Sheehan, Cooper, Holland, \& Cieri, 2007).

\subsection{Analysis method}

The study started with the descriptive statistical analysis, which is followed by multiple regression analysis to test the hypothesis by using SPSS ver.22. In order to examine the mediating role of job satisfaction in the relationship between HPHR and OCB, the four-step regression analysis was used (Baron \& Kenny, 1986; James \& Brett, 1984; Judd \& Kenny, 1981) to identify whether job satisfaction enhances the effect of HPHR on OCB in this research context or not. According to this method, there are three conditions that need to satisfy. Firstly, the causal and effect relationship between independent variable (HPHR) and dependent variable (OCB) is tested. Secondly, the correlation relationship between independent variable (HPHR) and mediating variable (job satisfaction) must be significant. Thirdly, the relationship between mediating variable (job satisfaction) and dependent variable (OCB) also must be demonstrated. Finally, the multiple regression between independent variable (HPHR), mediating variable (job satisfaction) and dependent variable (OCB) is investigated to identify the role of mediating variable. In case the influence of independent variable (HPHR) on dependent variable (OCB) is reduced but still significant. The result fits with a partial mediation model. On the other hand, the relationship between independent variable (HPHR) on dependent variable (OCB) is not significant anymore. The result fits with a full mediation model. In addition, this study also used bootstrapping to evaluate whether the indirect effects of the independent variable on the dependent variable through the mediator were statistically significant. In bootstrapping, the study employed the PROCESS software developed by Hayes. In bootstrapping, statistical significance is established when the confidence interval generated by repeated sampling does not contain zero (Edwards \& Lambert, 2007). Moreover, based on the normal theory approach, the study also employed the Sobel's test (Sobel, 1982) for indirect effect. 


\section{Results}

\subsection{Descriptive statistics}

Before doing regression analysis, the Pearson correlation coefficient (r) is examined with the intention of evaluating the correlations among variables. The analysis results in a correlation matrix among variables are shown in Table 3 . The absolute size of the number indicates the magnitude of the correlation of two variable and the sign reveals the direction of relationship (Christensen et al., 2011). With all Sig. values at the 0.01 level, the results show that there is the positive correlation among research variables. In detail, HPHR has a strong positive correlation with job satisfaction at Pearson Correlation coefficient of 0.614. Similarly, the HPHR and OCB have a strong positive correlation at Pearson correlation coefficient of 0.451 . Job satisfaction and OCB also possess the same trend with the relatively higher value of Pearson Correlation coefficient at 0.632 . The above outcome demonstrated the appropriateness to apply regression analysis to this set of data.

Table 3

Descriptive statistics and Correlations

\begin{tabular}{|c|c|c|c|c|c|c|c|c|c|}
\hline & Variables & Mean & SD & 1 & 2 & 3 & 4 & 5 & 6 \\
\hline 1 & HPHR system & 4.750 & .8786 & 1 & & & & & \\
\hline 2 & Job satisfaction & 4.421 & .7704 & $.614^{* *}$ & 1 & & & & \\
\hline 3 & OCB & 4.736 & .7169 & $.451^{* *}$ & $.632^{* *}$ & 1 & & & \\
\hline 4 & Size & 2.905 & 1.6065 & .083 & .134 & .145 & 1 & & \\
\hline 5 & Industrial sector & 1.659 & .7940 & -.036 & -.095 & -.101 & .045 & 1 & \\
\hline 6 & Type & 1.531 & .9198 & -.037 & .055 & .119 & $.205^{* *}$ & .103 & 1 \\
\hline 7 & Tenure & 2.827 & 1.0322 & .100 & .072 & .014 & -.091 & $-.210^{* *}$ & -.057 \\
\hline
\end{tabular}

Besides, the mean values of three factors felt in the range from 4.4 to 4.7 out of 7.0. It means that most of the respondents agree with these statements in the questionnaire. Specifically, HPHR system has a mean of $4.750(\mathrm{SD}=0.8786)$, mean of job satisfaction is $4.421(\mathrm{SD}=0.7704)$, and $\mathrm{OCB}$ has a mean of $4.736(\mathrm{SD}=0.7169)$. This provides the initial outcome that would be supportive for the proposed hypotheses. To demonstrate the research hypotheses, the further analyses are very essential.

\subsection{Hierarchical multiple regression analysis}

To test the three first hypotheses, linear regression analysis will be employed. This is also the most widely statistical analysis using to explore the relationship among quantitative variables (Christensen, Johnson, Turner, \& Christensen, 2011, p. 418). In this statistical analysis, two quantitative variables will be analyzed to indicate the correlation. With the support of SPSS, the degree of influence of independent variable on dependent variable is also indicated. Table 4 displays the results of regression analysis. In model 1, the dependent variable was OCB. Except independent variable, HPHR system, all the control variables had no significant effect on OCB. Consistent with our prediction, HPHR system was found to have a significant and positive effect on OCB with $\beta=0.3665, \mathrm{p}<0.01$. The value of $\mathrm{R}$-square in model 1 is 0.2405 which means that $24.05 \%$ of variance in OCB is explained by HPHR system. Upon the result, the Hypothesis 1 is supported. This finding is also supported by studies conducted by Morrison (1996) and Sun et al. (2007). Similarly, the model 2 and model 4 showed the results of regression analysis between job satisfaction and $\mathrm{OCB}, \mathrm{HPHR}$ and job satisfaction. In model 2, job satisfaction was also found to have significant and positive effect on OCB $(\beta=0.5750, p<0.01)$. Turning to model 4 , the study obtained the similar results, which indicated the significant and positive relationship between HPHR system and job satisfaction $(\beta=0.5325$, $\mathrm{p}<0.01$ ). Besides, with R-square $=0.3948$ in model 4 , it means that $39.48 \%$ of the differences of observed level of job satisfaction can be explained by differences of HPHR. In view of the above, both hypothesis 2 and hypothesis 3 were supported. The hypotheses 1, 2, 3 were supported and thereby satisfying three first requirements for mediation examination. The final condition is that the multiple regression analysis between the independent variable (HPHR), mediating variable (job satisfaction) and the dependent variable (OCB) is tested to identify the role of mediating variable.

Table 4

Hierarchical Multiple Regression results for testing mediation

\begin{tabular}{|c|c|c|c|c|}
\hline \multirow[b]{2}{*}{ Variables and statistic } & 1-OCB & \multicolumn{3}{|c|}{ 2- Job satisfaction } \\
\hline & $\begin{array}{l}\text { Model 1 } \\
\text { Beta }(\beta)\end{array}$ & $\begin{array}{l}\text { Model } 2 \\
\text { Beta }(\beta) \\
\end{array}$ & $\begin{array}{l}\text { Model 3 } \\
\text { Beta }(\beta) \\
\end{array}$ & $\begin{array}{l}\text { Model } 4 \\
\text { Beta }(\beta) \\
\end{array}$ \\
\hline HPHR system & $0.3665^{* *}$ & & 0.0962 & $0.5325^{* *}$ \\
\hline Job satisfaction & & $0.5750^{* *}$ & $0.5077^{* * *}$ & \\
\hline Size & 0.0371 & 0.020 & 0.0193 & 0.0350 \\
\hline Industrial sector & -0.0993 & -0.054 & -0.0587 & -0.0800 \\
\hline Type & 0.0995 & 0.062 & 0.0689 & 0.0602 \\
\hline Tenure & -0.0275 & -0.024 & -0.0292 & 0.0033 \\
\hline $\mathbf{F}$ & $10.9560^{* *}$ & $24.256^{* *}$ & $20.8131^{* *}$ & $22.5675^{* *}$ \\
\hline $\mathbf{R}$ & 0.4904 & 0.6420 & 0.6486 & 0.6283 \\
\hline R-Square & 0.2405 & 0.4120 & 0.4206 & 0.3948 \\
\hline
\end{tabular}

As shown in Table 4, results in model 3 reveals that when both independent variables - HPHR and mediating variables - job satisfaction were simultaneously added into the model, the original significant effect of HPHR system on OCB disappeared $(\beta=0.0962, p=0.1137>0.1)$. Meanwhile, job satisfaction was still significantly related to $\mathrm{OCB}$ at $\beta=0.5077$ and $\mathrm{p}<0.01$. 
These results indicate that job satisfaction fully mediated the linkage between HPHR system and OCB. The bootstrapping further was employed to test the statistical significance of indirect effects. Based on our sample, we conducted the bootstrapping procedure (Preacher \& Hayes, 2008) with 10,000 random samples using a 95 percent confidence level. The point estimate for the indirect effect of HPHR system on OCB via job satisfaction was 0.2703 (95 percent confidence interval: 0.1839 , 0.3676). Since the 95 percent confidence intervals of job satisfaction did not contain zero (Preacher \& Hayes, 2008), it was concluded that job satisfaction fully mediated the effect of HPHR system on OCB. In addition, the Sobel's test (Sobel, 1982) was also used to test the indirect effect between independent variable - HPHR system, and dependent variable - OCB through mediating variable - job satisfaction. Results in Sobel's test showed the value of $\mathrm{z}$ is 5.9156 (this value is more than 1.96, $\mathrm{p}<0.01)$. This result reveals that the mediating effect of job satisfaction on the HPHR - OCB relationship is significant $(\mathrm{p}<0.01)$. Therefore, the hypothesis 4 was supported. The results of testing hypotheses are summarized below:

Table 5

Hypothesis testing results

\begin{tabular}{llll}
\hline & Hypothesis & Route Coefficient & \\
\hline H1 & HPHR $\rightarrow$ OCB & $0.3665^{* *}$ & Result \\
H2 & HPHR $\rightarrow$ Job satisfaction & $0.5325^{* *}$ & Supported \\
H3 & Job satisfaction $\rightarrow$ OCB & $0.5750^{* *}$ & Supported \\
H4 & Mediating impact of Job satisfaction in the impact of HPHR on OCB & $0.5077^{* *}(0.0962)$ & Supported \\
\hline Significance at the 0.01 level & & Supported \\
\hline
\end{tabular}

\section{Discussion}

The primary objective of this research is to explore the mediating mechanism through which HPHR system influence OCB through employee attitude toward their job satisfaction. The study examined to what extent HPHR system influences employee's OCB in Vietnamese context. The study is expected to contribute the understanding towards mediating mechanism in HR-employee behavior relationship at the individual level. Overall, the findings of this research indicated that the implementation of HPHR system positively influence employee's OCB. In addition, the mediating role of job satisfaction in this interaction also has been clearly demonstrated. The result of the present study also supports for previous investigations regarding HPHR in the prediction of HR outcomes that contribute to organizational effectiveness. The findings support for the proposed hypotheses that indicated the HPHR system has not only directly influence the employee's behavior through organizational citizenship behavior but also indirectly affect the employees' attitude of job satisfaction. Moreover, this empirical investigation along with some recent research that conducted on HPWS in Asian countries like China, India (Gong et al., 2010; Jiang \& Liu, 2015; Muduli, Verma, \& Datta, 2016; Snape \& Redman, 2010b; Sun et al., 2007), provides evidence against the assumption that strategic HRM with integrated HR practices is only applicable in Western context. This finding contributes one more Asian countries context that can be employed HPHR theory in HRM. Thus, the HPHR theory is completely considered as a universal theory that can be applied in multinational context especially in some emerging and developing economies like Vietnam. Our study also added to the understanding in term of HRM literature from social exchange perspective, in which, the way HPRH system influence employees' OCB through the feeling of job satisfaction. In addition, in this research, HPHR system is measured as an integrated system but separated components (Guthrie, 2001) to investigate the interaction of a complete bundle of HR practice on the mediating variable and dependent variables. These results enhance the importance of the strategic human resource management approach within organizations. Concerning practical implication, the findings of this study may be meaningful and useful for those organizations finding the way to implement the human resource practices to foster the employee's outcome that contributes to the overall organizational performance. The organizations can implement and adjust their HPHR system in many steps from staffing, training, rewarding, enhancing the job opportunities that could create the improvement and development of employees' competency. Besides, the implementation of HR practices with the involvement of organizational strategies and in the integration of multiple components instead of individual components is very necessary. This approach would enhance the employees and organizational performance strongly. Moreover, the intervening effect of attitudinal factors like job satisfaction in the process HPHR influence on employees' behaviors is very significant. The company management needs to pay attention to job satisfaction that play an important role in the contribution of organizational outcomes. The managerial policies and practices need to take careful consideration of this element.

\section{Limitation and future research directions}

There are several limitations of this present study that may have influenced the results obtained and addressed in the future works. Firstly, the limitation of potential generalizability of the research findings. The study tested the hypotheses based on the set of data that collected from line managers in three large cities in Vietnam. With a set of 179 responses could not generalize to the whole population. Hence, future research might investigate with a larger and more diverse sample with more reliable sampling methods. This will remedy this issue. Secondly, a cross-sectional study was conducted by obtaining data at one point in time at the individual level, which limits our conclusion related to cause-effect relations inferred from our results. Moreover, the individual level evaluated both independent and dependent variables. Thus, the future research might be based on a longitudinal design with multilevel analysis that definitely leads to more reliable and comprehensive result. In addition, this study measured the variables by obtaining the perceptual performance data from individuals. However, the HPHR could be measured through organizational performance. Besides, organizational effectiveness is multidimensional that could be 
measured through several defensible dimensions such as: HR outcomes, organizational outcome, or financial and accounting outcomes (Way \& Johnson, 2005). Future research should measure the outcome of HPHR implementation through multiple measurements such as employee retention, productivity, or financial measures (return on investment, profitability). Finally, this study only focused on exploring mediating mechanism through which HPHR practices influenced OCB, and has not investigated contextual factors which may moderate this interaction. Future work should deal with the other factor as mediators of the causality relation and contextual factors as moderators of this relationship.

\section{Acknowledgement}

This paper is as part of the research project "University and Enterprise collaboration in facilitating lifelong learning: international experience and solutions for Vietnam”, coded CT.2019.07.05, financed by Ministry of Education and Training, Vietnam.

\section{References}

Alfes, K., Shantz, A., Truss, C., \& Soane, E. (2013). The link between perceived human resource management practices, engagement and employee behaviour: a moderated mediation model. The International Journal of Human Resource Management, 24(2), 330-351.

Appelbaum, E. (2000). Manufacturing advantage: Why high-performance work systems payoff: Cornell University Press.

Arthur, J. B. (1994). Effects of human resource systems on manufacturing performance and turnover. Academy of Management Journal, $37(3), 670-687$.

Bateman, T. S., \& Organ, D. W. (1983). Job satisfaction and the good soldier: The relationship between affect and employee "citizenship". Academy of Management Journal, 26(4), 587-595.

Becker, B., \& Gerhart, B. (1996). The impact of human resource management on organizational performance: Progress and prospects. Academy of Management Journal, 39(4), 779-801.

Becker, B. E., Huselid, M. A., Pickus, P. S., \& Spratt, M. F. (1997). HR as a source of shareholder value: Research and recommendations. Human Resource Management, 36(1), 39-47.

Blau, P. M. (1964). Exchange and power in social life: Transaction Publishers.

Christensen, L. B., Johnson, B., Turner, L. A., \& Christensen, L. B. (2011). Research methods, design, and analysis.

Collins, C. J., \& Smith, K. G. (2006). Knowledge exchange and combination: The role of human resource practices in the performance of high-technology firms. Academy of Management Journal, 49(3), 544-560.

Combs, J., Liu, Y., Hall, A., \& Ketchen, D. (2006). How much do high-performance work practices matter? A meta-analysis of their effects on organizational performance. Personnel Psychology, 59(3), 501-528.

Datta, D. K., Guthrie, J. P., \& Wright, P. M. (2005). Human resource management and labor productivity: does industry matter? Academy of Management Journal, 48(1), 135-145.

Delaney, J. T., \& Huselid, M. A. (1996). The impact of human resource management practices on perceptions of organizational performance. Academy of Management journal, 39(4), 949-969.

Delery, J. E., \& Doty, D. H. (1996). Modes of theorizing in strategic human resource management: Tests of universalistic, contingency, and configurational performance predictions. Academy of Management Journal, 39(4), 802-835.

George, J. M., \& Jones, G. R. (1997). Organizational spontaneity in context. Human performance, 10(2), 153-170.

Gong, Y., Chang, S., \& Cheung, S. Y. (2010). High performance work system and collective OCB: A collective social exchange perspective. Human Resource Management Journal, 20(2), 119-137.

Gould-Williams, J., \& Mohamed, R. (2010). A comparative study of the effects of 'best practice' HRM on worker outcomes in Malaysia and England local government. The International Journal of Human Resource Management, 21(5), 653-675.

Guest, D., Conway, N., \& Dewe, P. (2004). Using sequential tree analysis to search for 'bundles' of HR practices. Human Resource Management Journal, 14(1), 79-96.

Guest, D. E. (1997). Human resource management and performance: a review and research agenda. International Journal of Human Resource Management, 8(3), 263-276.

Guest, D. E. (1999). Human resource management-the workers' verdict. Human Resource Management Journal, 9(3), 5-25.

Guest, D. E. (2004). The psychology of the employment relationship: An analysis based on the psychological contract. Applied Psychology, $53(4), 541-555$

Guthrie, J. P. (2001). High-involvement work practices, turnover, and productivity: Evidence from New Zealand. Academy of Management Journal, 44(1), 180-190.

Guzzo, R. A., \& Noonan, K. A. (1994). Human resource practices as communications and the psychological contract. Human Resource Management, 33(3), 447-462.

Hannah, D., \& Iverson, R. (2004). Employment relationships in context: Implications for policy and practice. The employment relationship: Examining Psychological and Contextual Perspectives, 332-350.

Harley, B. (2002). Employee responses to high performance work system practices: An analysis of the AWIRS95 data. The Journal of Industrial Relations, 44(3), 418-434.

Huselid, M. A. (1995). The impact of human resource management practices on turnover, productivity, and corporate financial performance. Academy of Management Journal, 38(3), 635-672.

Ichniowski, C., Shaw, K., \& Prennushi, G. (1997). The effects of human resource management practices on productivity: A study of steel finishing lines. The American Economic Review, 291-313.

Jehn, K. A., Northcraft, G. B., \& Neale, M. A. (1999). Why differences make a difference: A field study of diversity, conflict and performance in workgroups. Administrative Science Quarterly, 44(4), 741-763.

Kehoe, R. R., \& Wright, P. M. (2013). The impact of high-performance human resource practices on employees' attitudes and behaviors. Journal of Management, 39(2), 366-391.

Leana, C. R., \& Van Buren, H. J. (1999). Organizational social capital and employment practices. Academy of Management Review, 24(3), 538-555. 
Lepak, D. P., Liao, H., Chung, Y., \& Harden, E. E. (2006). A conceptual review of human resource management systems in strategic human resource management research. Research in Personnel and Human Resources Management, 25(1), 217-271.

Lepak, D. P., \& Snell, S. A. (1999). The human resource architecture: Toward a theory of human capital allocation and development. Academy of Management Review, 24(1), 31-48.

MacDuffie, J. P. (1995). Human resource bundles and manufacturing performance: Organizational logic and flexible production systems in the world auto industry. Industrial \& Labor Relations Review, 48(2), 197-221.

MacKenzie, S. B., Podsakoff, P. M., \& Ahearne, M. (1998). Some possible antecedents and consequences of in-role and extra-role salesperson performance. The Journal of Marketing, 87-98.

Macky, K., \& Boxall, P. (2007). The relationship between 'high-performance work practices' and employee attitudes: an investigation of additive and interaction effects. The International Journal of Human Resource Management, 18(4), 537-567.

Moorman, R. H. (1991). Relationship between organizational justice and organizational citizenship behaviors: Do fairness perceptions influence employee citizenship? Journal of Applied Psychology, 76(6), 845.

Moorman, R. H., Niehoff, B. P., \& Organ, D. W. (1993). Treating employees fairly and organizational citizenship behavior: Sorting the effects of job satisfaction, organizational commitment, and procedural justice. Employee Responsibilities and Rights Journal, 6(3), 209225.

Morrison, E. W. (1996). Organizational citizenship behavior as a critical link between HRM practices and service quality. Human Resource Management (1986-1998), 35(4), 493.

O'Reilly, C. A., \& Chatman, J. (1986). Organizational commitment and psychological attachment: The effects of compliance, identification, and internalization on prosocial behavior. Journal of Applied Psychology, 71(3), 492.

Organ, D. W. (1988). Organizational citizenship behavior: The good soldier syndrome: Lexington Books/DC Heath and Com.

Organ, D. W. (1990). The motivational basis of organizational citizenship behavior. Research in Organizational Behavior, 12(1), $43-72$.

Organ, D. W., \& Ryan, K. (1995). A meta-analytic review of attitudinal and dispositional predictors of organizational citizenship behavior. Personnel Psychology, 48(4), 775-802.

Paauwe, J. (2009). HRM and performance: Achievements, methodological issues and prospects. Journal of Management Studies, 46(1), $129-142$.

Pfeffer, J. (1994). Competitive advantage through people. California Management Review, 36(2), 9.

Pittino, D., Visintin, F., Lenger, T., \& Sternad, D. (2016). Are high performance work practices really necessary in family SMEs? An analysis of the impact on employee retention. Journal of Family Business Strategy, 7(2), 75-89.

Podsakoff, P. M., MacKenzie, S. B., Paine, J. B., \& Bachrach, D. G. (2000). Organizational citizenship behaviors: A critical review of the theoretical and empirical literature and suggestions for future research. Journal of Management, 26(3), 513-563.

Preacher, K. J., \& Hayes, A. F. (2008). Asymptotic and resampling strategies for assessing and comparing indirect effects in multiple mediator models. Behavior Research Methods, 40(3), 879-891.

Rhoades, L., \& Eisenberger, R. (2002). Perceived organizational support: a review of the literature: American Psychological Association.

Rousseau, D. M., \& Greller, M. M. (1994). Human resource practices: Administrative contract makers. Human Resource Management, 33(3), 385-401.

Settoon, R. P., Bennett, N., \& Liden, R. C. (1996). Social exchange in organizations: Perceived organizational support, leader-member exchange, and employee reciprocity. Journal of Applied Psychology, 81(3), 219.

Shaw, J. D., Dineen, B. R., Fang, R., \& Vellella, R. F. (2009). Employee-organization exchange relationships, HRM practices, and quit rates of good and poor performers. Academy of Management Journal, 52(5), 1016-1033.

Smith, C., Organ, D. W., \& Near, J. P. (1983). Organizational citizenship behavior: Its nature and antecedents. Journal of Applied Psychology, 68(4), 653.

Snape, E., \& Redman, T. (2010). HRM practices, organizational citizenship behaviour, and performance: A multi-level analysis. Journal of Management Studies, 47(7), 1219-1247.

Sobel, M. E. (1982). Asymptotic confidence intervals for indirect effects in structural equation models. Sociological Methodology, 13(1982), 290-312.

Sun, L.-Y., Aryee, S., \& Law, K. S. (2007). High-performance human resource practices, citizenship behavior, and organizational performance: A relational perspective. Academy of Management Journal, 50(3), 558-577.

Takeuchi, R., Chen, G., \& Lepak, D. P. (2009). Through the looking glass of a social system: Cross-level effects of high-performance work systems on employees'attitudes. Personnel Psychology, 62(1), 1-29.

Tsui, A. S., Pearce, J. L., Porter, L. W., \& Tripoli, A. M. (1997). Alternative approaches to the employee-organization relationship: Does investment in employees pay off? Academy of Management journal, 40(5), 1089-1121.

Way, S. A. (2002). High performance work systems and intermediate indicators of firm performance within the US small business sector. Journal of Management, 28(6), 765-785.

Way, S. A., \& Johnson, D. E. (2005). Theorizing about the impact of strategic human resource management. Human Resource Management Review, 15(1), 1-19.

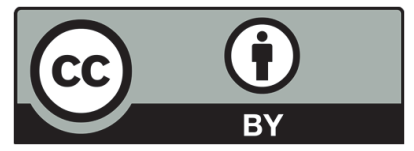

(C) 2020 by the authors; licensee Growing Science, Canada. This is an open access article distributed under the terms and conditions of the Creative Commons Attribution (CC-BY) license (http://creativecommons.org/licenses/by/4.0/). 